\title{
Experimental and Computational Investigations of Decolourization of Rhodamine B in Aqueous Solution
}

\author{
Sulu Çözeltide Rodamin B'nin Renk Gideriminin Deneysel ve \\ Hesaplamalı Araştırılması
}

\author{
Research Article
}

Nuket Kartal Temel* and Koray Sayın

Department of Chemistry, Faculty of Science, Cumhuriyet University, Sivas, Turkey.

\section{A B S TRACT}

\footnotetext{
T
} he aim of the study was comparatively to investigate decolourization of Rhodamine $B(R h B)$ in aqueous solution using photocatalytic and ultrasonic processes. Also, computational investigations of $\mathrm{RhB}^{\circ}$ and $\mathrm{RhB}^{+}$ compounds were performed at HF/6-31G level in gas phase. Photocatalytic decolourization of RhB was studied using $\mathrm{TiO}_{2}$ and silver-loaded $\mathrm{TiO}_{2}\left(\mathrm{Ag}-\mathrm{TiO}_{2}\right)$ as catalyst. It was found that decolourization by photocatalytic process of $\mathrm{RhB}$ increased with decreasing $\mathrm{pH}$, and decolourization rate also increased in the presence of $\mathrm{TiO}_{2} /$ UV when compared to UV irradiation alone. Moreover, Ag-loading to $\mathrm{TiO}_{2}$ dramatically reduced decolourization time. The decolourization by ultrasonic process of RhB was also studied by using various salts and initial dye concentrations at various $\mathrm{pHs}$ and amplitudes. The decolourization by ultrasonic process of RhB was found to increase with decreasing $\mathrm{pH}$, increasing amplitudes and addition of various salts to aqueous solution. It was observed that the decolourization decreased with increasing initial RhB concentration. The decolourization rate of the dye was monitored spectrophotometrically at $554 \mathrm{~nm}$.

\section{Key Words}

Dye, photocatalytic decolourization, ultrasonic decolourization, silver, titanium dioxide, Ab-initio study.

\section{öz}

u çalışmanın amacı fotokatalitik ve ultrasonik yöntem ile sulu çözeltideki Rodamin B (RhB)'nin renk gideriminin karşılaştırmalı olarak araştırılmasıdır. Ayrıca, RhB ${ }^{\circ}$ and $\mathrm{RhB}^{+-}$nin gaz fazında HF/6-31G seviyesindeki hesaplamalı araştırılması da yapılmıştır. RhB'nin fotokatalitik renk gideriminde $\mathrm{TiO}_{2}$ ve gümüş yüklü $\mathrm{TiO}_{2}\left(\mathrm{Ag}-\mathrm{TiO}_{2}\right)$ katalit olarak kullanılmıştır. RhB nin fotokatalitik yöntemle renk gideriminin azalan $\mathrm{pH}$ ile arttığı, ayrıca renk giderim oranının sadece UV ışığı ile ışınlamayla kıyaslandığında $\mathrm{TiO}_{2} / U V$ varlığında daha da arttığı gözlenmiştir. Ag-yüklü $\mathrm{TiO}_{2}$ in kullanılması ise renk giderme zamanını önemli ölçüde azaltmıştır. RhB nin renk gideriminde çeşitli tuzların, farklı pH'larda boya başlangıç derişiminin ve ses dalgası şiddetinin etkisinin de araştırıldığı ultrasonik yöntemle de çalışı Imıştır. RhB nin ultrasonik yöntemle renk gideriminin azalan $\mathrm{pH}$, artan ses şiddeti ve sulu çözeltiye eklenilen çeşitli tuzların etkisiyle arttığı gözlenmiştir. Renk gideriminin RhB başlangıç derişiminin artmasıyla azaldığı gözlenmiştir. Boyanın renk giderim oranı 554 nm'de spektrofotometrik olarak izlenmiştir.

\section{Anahtar Kelimeler}

Boya, fotokatalitik renk giderimi, ultrasonik renk giderimi, gümüş, titanyum dioksit, Ab-initio çalışma.

Article History: Received: Apr 10, 2017; Revised: Jun 21, 2017; Accepted: Oct 10, 2017; Available Online: Dec 25, 2017. DOI: 10.15671/HJBC.2018.178

Correspondence to: N.K. Temel, Department of Chemistry, Faculty of Science, Cumhuriyet University, Sivas, Turkey. 


\section{INTRODUCTION}

Synthetic dyes are widely used in the textile, $\int$ cosmetic, paper dyeing, drug and food processing industries. The industry wastewater is heavily charged with unconsumed dyes, surfactants and sometimes traces of metals. These effluents cause a lot of damage to the environment [1]. RhB is one of the most important dyes of the xanthene group and is used in many industrial processes, such as paper dyeing and the production of dye laser [2]. Advanced oxidation processes (AOPs) are quite appropriate for the remediation of wastewater as a pre- or post-treatment step. The AOPs are mainly based on the generation of the hydroxyl radical $(\mathrm{OH} \cdot)_{\text {, }}$ which has a great oxidation power and is able to oxidize almost all organic compounds to carbon dioxide and water. Heterogeneous photocatalysis through illumination of UV on semiconductor surface is an attractive AOP [3]. Titanium dioxide $\left(\mathrm{TiO}_{2}\right)$, as a chemically stable, non-toxic, highly efficient, and relatively inexpensive photocatalyst, has been widely used for water and air purification since many environmental pollutants can be degraded by oxidation and reduction processes on $\mathrm{TiO}_{2}$ surface $[4,5]$. Photocatalytic oxidation processes are usually referred to as advanced oxidation processes (AOP). When a photon with an energy which matches or exceeds the band gap energy of the semi-conductor is incident on a semiconductor surface, a conductive band electron will jump to its valence band leaving a positively charged hole behind. The initial step in this type of photo-oxidation process is believed to be the formation of free hydroxyl radicals [6-8]. Hydroxyl radicals are generated by the oxidation of water $\left(\mathrm{OH}^{-}\right.$ions) at the valence band positively charged holes.

$$
\begin{aligned}
& \mathrm{TiO}_{2(s)} \mathrm{TiO}_{2(s)}+h \rightarrow e_{\mathbb{B}}^{-}+h_{\mathbb{B}}^{+} \\
& h_{\mathbb{B}}^{+}+\boldsymbol{\theta} \underset{\left(\text { TiO }_{2} \text { surface }\right)}{-} \rightarrow \boldsymbol{\theta} \cdot \\
& h_{\mathbb{B}}^{+}+H_{2} O_{(\text {adsorbed a surface })} \rightarrow \boldsymbol{A} \cdot+H^{+} \\
& \boldsymbol{A} \cdot+\text { Organic Molecule } \rightarrow \text { Degradation products }
\end{aligned}
$$

On the other hand, the dissolved $\mathrm{O}_{2}$ molecules are transformed to anionic superoxide $\left(\mathrm{O}_{2}^{-\bullet}\right)$ radicals via electrons from conductive band.

$e_{\mathfrak{B}}^{-}+O_{2 \text { (adsorbed a } \text { surface })} \rightarrow \mathrm{O}_{2}^{-\bullet}$

The most commonly studied photocatalysts are $\mathrm{TiO}_{2}, \mathrm{ZnO}, \mathrm{ZnS}$ and $\mathrm{CdS}$. Additionally, $\mathrm{In}_{2} \mathrm{O}_{3^{\prime}} \mathrm{SrTiO}_{3^{\prime}}$, $\mathrm{SnO}_{2}$ and $\mathrm{WO}_{3}$ have been used as photocatalysts but all showed lower levels of photo-activity [9], and $\mathrm{SiO}_{2}$ and $\mathrm{MgO}$ are found to be inactive. Since most metal oxides and sulphides can undergo irreversible photo-corrosion on the surface [10], these types of semiconductor are not suitable for long term treatment processes. Transition metal doping with silver which enhances the interfacial charge-transfer reactions of $\mathrm{TiO}_{2}$ bulk phase and colloidal particles, can increase the photocatalytic activity of $\mathrm{TiO}_{2}[11]$.

In recent years considerable interest has been shown on the application of ultrasonic decolourization for the removal of hazardous contaminants from water [12,13]. Ultrasonic decomposition of organic compounds is resulted from the formation, growth and collapse of highenergy cavitation bubbles, which releasing large quantities of energy over a small location [14]. When water is sonicated, $\mathrm{H}^{\cdot}$ and $\mathrm{OH}^{*}$ are produced. A simple mechanism for radical formation and depletion, during sonication of water is given below [13]:

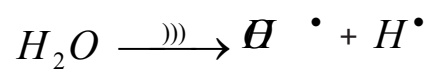

$$
\begin{aligned}
& \boldsymbol{\theta}^{\bullet}+\boldsymbol{\theta} \cdot \rightarrow \mathrm{H}_{2} \mathrm{O}_{2} \\
& \boldsymbol{\theta}^{\bullet}+\mathrm{H}^{\bullet} \rightarrow \mathrm{H}_{2} \mathrm{O} \\
& H^{\bullet}+H^{\bullet} \rightarrow \mathrm{H}_{2}
\end{aligned}
$$

There is an equilibrium in $\mathrm{RhB}^{\circ}$ and $\mathrm{RhB}^{+-}$which their color are colorless and violet, respectively [15]. Shematic diagram of $\mathrm{RhB}^{0}$ and $\mathrm{RhB}^{+-}$are represented in Scheme 1.

Optimized structures of $\mathrm{RhB}^{\circ}$ and $\mathrm{RhB}^{+-}$ are calculated at HF/6-31G level in gas phase. Additionally, chemical reactivity of these compounds are examined in detail by using some quantum chemical descriptors which are energy of the highest occupied molecular orbital $\left(\mathrm{E}_{\text {номо }}\right)$, 

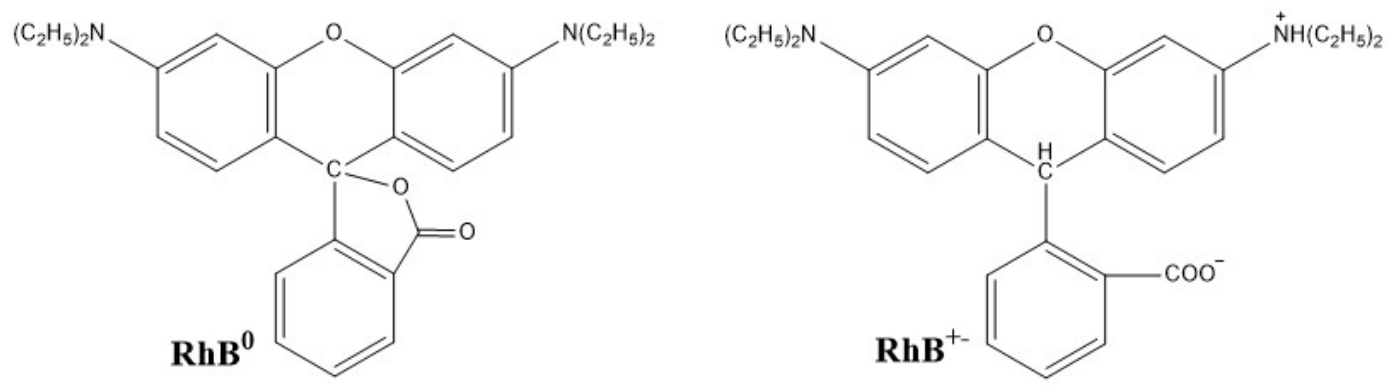

Scheme 1. Schematic representation of $\mathrm{RhB}^{\circ}$ and $\mathrm{RhB}^{+-}$.

energy of the lowest unoccupied molecular orbital $\left(\mathrm{E}_{\text {LUMO }}\right)$, energy gap between LUMO and HOMO $\left(\mathrm{E}_{G A P}\right)$, softness $(\sigma)$, chemical potential $(C P)$, nucleophilicity index $(\mathrm{N})$ and dipole moment $(\mu)$.

\section{MATERIAL and METHODS}

\section{Experimental Method Reagents and Solutions}

RhB was obtained from Merck (Darmstad, Germany). The stock solution of RhB was prepared in deionised water in all experiments. $\mathrm{H}_{2} \mathrm{SO}_{4}$ and $\mathrm{NaOH}$ solutions at $1.0 \mathrm{~mol} \mathrm{~L}^{-1}$ were used to adjust the $\mathrm{pH}$ of the studied dye samples. Solid reagents of $\mathrm{Na}_{2} \mathrm{CO}_{3}, \mathrm{NaHCO}_{3}, \mathrm{NaCl}, \mathrm{Na}_{2} \mathrm{SO}_{3}$ and $\mathrm{NaIO}_{3}$ were supplied from Merck. Titanium dioxide (anatase $99.9 \%$ ) was supplied by Aldrich (surface area $9.35 \mathrm{~m}^{2} \mathrm{~g}^{-1}$ ). The $\mathrm{Ag}$-loaded titanium dioxide containing $1 \%(\mathrm{w} / \mathrm{w})$ silver was prepared following the method described previously [16]. Initially, 9.2 $\mathrm{mL}$ of a $0.1 \mathrm{~mol} \mathrm{~L}^{-1}$ solution of $\mathrm{AgNO}_{3}$ was added to a aqueous $\mathrm{TiO}_{2}$ slurry (which contained $10.0 \mathrm{~g}$ of $\left.\mathrm{TiO}_{2}\right)$, followed by about $10 \mathrm{~mL}$ of a $1 \%(\mathrm{w} / \mathrm{w})$ solution of $\mathrm{Na}_{2} \mathrm{CO}_{3}$. The aqueous suspension was dried at room temperature and then baked for 6 $\mathrm{h}$ at $600^{\circ} \mathrm{C}$ (surface area $8.49 \mathrm{~m}^{2} \mathrm{~g}^{-1}$ ).

\section{Photocatalytic Decolourization Experiments}

$100 \mathrm{~mL}$ of an aqueous dye sample and $0.1 \mathrm{~g} \mathrm{TiO}_{2}$ (neat $\mathrm{TiO}_{2}$ or $\mathrm{Ag}$-loaded $\mathrm{TiO}_{2}$ ) were initially placed in a $500 \mathrm{~mL}$ pyrex flask (which with covered with aluminium foil) with a condenser. The $\mathrm{pH}$ of dye sample solution was adjusted. The stirred suspension was illuminated by an OSRAM-Ultra Vitalux $300 \mathrm{~W}$ low pressure mercury lamp (no cut off filters) with a flux output of approximately $5.8 \mathrm{~W}$ near the $254 \mathrm{~nm}$ wavelength. At regular intervals, $5 \mathrm{~mL}$ of aliquots of irradiated sample was withdrawn and centrifuged twice at 4000 rpm for 5 min to separate $\mathrm{TiO}_{2}$ for residual dye analysis. Concentrations of the residual dye in the supernatant were spectrophotometrically monitored for $60 \mathrm{~min}$ at $554 \mathrm{~nm}$.

\section{Ultrasonic Decolourization Experiments}

Sonolyses were performed with an ultrasonic processor (Cole Parmer Instruments, Vernon Hills, Illinois, USA) operating at $20 \mathrm{kHz}$ and $25{ }^{\circ} \mathrm{C}$. In each experiment, $250 \mathrm{~mL}$ of aqueous dye sample with desired concentration was placed in to a $500 \mathrm{~mL}$ pyrex flask and its $\mathrm{pH}$ was adjusted. The solution was poured into ultrasonic processor and mechanical stirrer was used to stir the solution. At certain reaction intervals, $5 \mathrm{~mL}$ of sample was withdrawn. Concentrations of the residual dye in the supernatant were spectrophotometrically monitored for $60 \mathrm{~min}$ at $554 \mathrm{~nm}$. Also, by adding $\mathrm{Na}_{2} \mathrm{CO}_{3}, \mathrm{NaHCO}_{3}, \mathrm{NaCl}$ as well as reducing and oxidizing salts such as $\mathrm{Na}_{2} \mathrm{SO}_{3}$ and $\mathrm{NaIO}_{3}$ to the solution, their effects on degradation of $\mathrm{RhB}$ were investigated.

\section{Computational Method}

All computational processes were made by Gaussian package program [17,18]. Fully optimizations were performed at HF/6-31G level in gas phase and in these calculation results no imaginary frequencies were observed. Mentioned some quantum chemical parameters of $\mathrm{RhB}^{\circ}$ and $\mathrm{RhB}^{+-}$were calculated by using Equations (9)- (18):

$$
E_{G A P}=E_{L U M O}-E_{\text {HOMO }}
$$

$I=-E_{\text {Номо }}$

$$
A=-E_{L U M O}
$$




$$
\begin{aligned}
& \eta=\frac{I-A}{2} \\
& \sigma=\frac{1}{\eta} \\
& \chi=\frac{\left|E_{\text {HOMO }}+E_{\text {LUMO }}\right|}{2} \\
& C P=-\chi \\
& \omega=\frac{C P^{2}}{2 \eta} \\
& N=\frac{1}{\omega}
\end{aligned}
$$

\section{RESULTS and DISCUSSION}

\section{Photocatalytic Decolourization}

\section{Effect of $\mathrm{TiO}_{2}$ and UV on the Photocatalytic Decolourization of RhB}

A series of experiments using $\mathrm{RhB}$ dye was carried out in the presence of $\mathrm{TiO}_{2}$ particles with and without UV illumination. The same procedure was repeated with $\mathrm{Ag}$-loaded $\mathrm{TiO}_{2}$ and the results are given in Figure 1. Each data point shown in all figures represents the mean of three replications.

It is seen that Ag-loading dramatically reduced decolourization time for the $\mathrm{RhB}$ dye. While the undoped $\mathrm{TiO}_{2}$ decolorized about $47 \%$ of the initial amount within $10 \mathrm{~min}, \mathrm{Ag}$-loaded $\mathrm{TiO}_{2}$ decolorized $88 \%$ of the initial amount during the same time

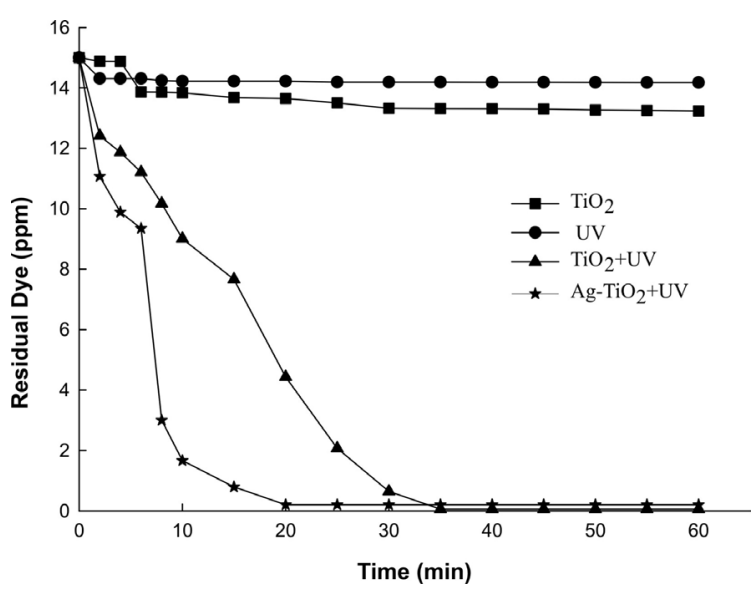

Figure 1. Photocatalytic decolourization of RhB versus irradiation time for several systems. period. As seen from Figure 1, decolourization of the dye was very slow in the absence of $\mathrm{TiO}_{2}$ with UV irradiation and the decolourization with only $\mathrm{TiO}_{2}$ without UV irradiation (in dark) is also very slow. The time required for complete decolourization is about 35-60 min with $\mathrm{TiO}_{2}$ and UV irradiation. With the Ag-loaded catalyst, the complete decolourization of dye took a short time of $20 \mathrm{~min}$.

As mentioned above, Ag-loading dramatically reduced decolourization time for the RhB dye. However, as seen in Figure 2, the increase in the amount of $\mathrm{Ag}-\mathrm{TiO}_{2}$ steadily affected the decolourization.

XRD pattern (as indicated in our first study, Figure 2) exhibited strong diffraction peaks at $25^{\circ}$ and $48^{\circ}$ indicating $\mathrm{TiO}_{2}$ in the anatase phase and Ag loading did not greatly affected the structure [16-18]. The formation of silver islands in $\mathrm{TiO}_{2}$ can be clearly seen in SEM image (Figure $4 b$, blue regions, in referred our study) [19] .

The enhancement of removal rate is due to: (i) the increase in the amount of catalyst increasing the number of dye molecule adsorbed and (ii) the increase in the density of particles in the area of illumination [20]. At $\mathrm{TiO}_{2}$ concentrations less than about $1.0 \mathrm{~g} \mathrm{~L}^{-1}$, the decolourization rate is proportional to the $\mathrm{TiO}_{2}$ concentration. The decolourization rate has probably been limited over $2.0 \mathrm{~g} \mathrm{~L}^{-1}$ of $\mathrm{TiO}_{2}$ because UV light can be blocked by catalyst itself.

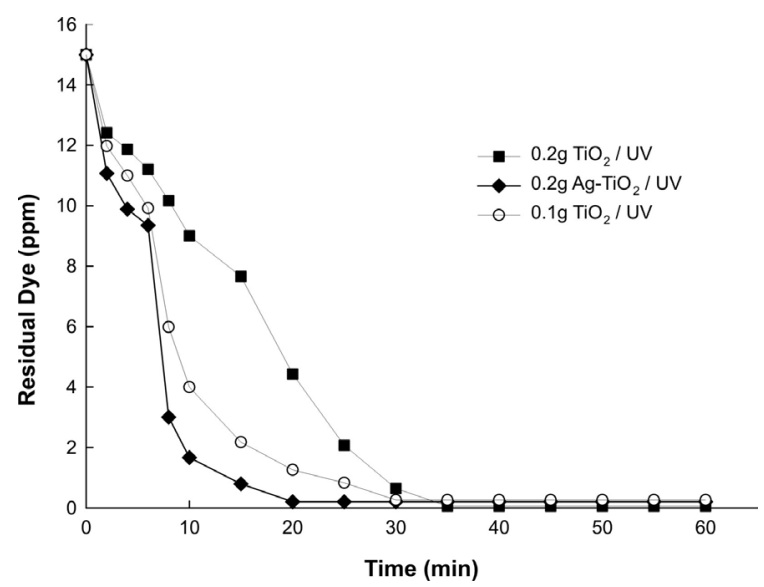

Figure 2. Photocatalytic decolourization of RhB versus irradiation time in $\mathrm{TiO}_{2} / \mathrm{UV}$ and different amount of $\mathrm{Ag}-\mathrm{TiO}_{2} /$ UV systems. 


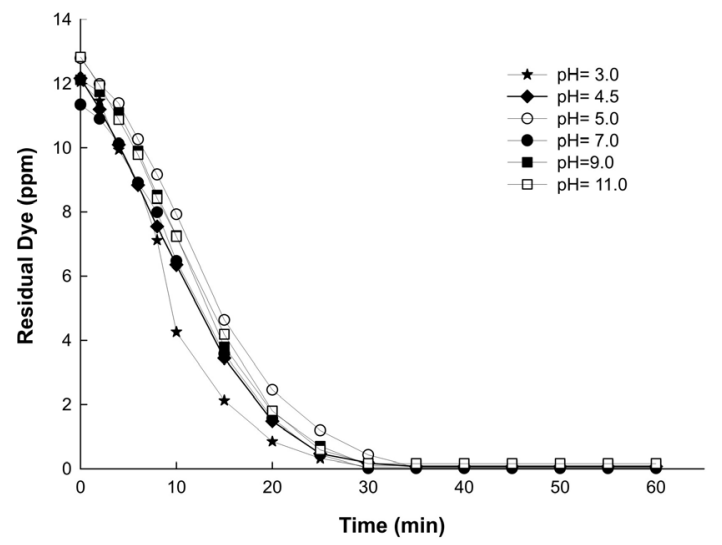

Figure 3. Effect of $\mathrm{pH}$ on the photocatalytic decolourization of RhB.

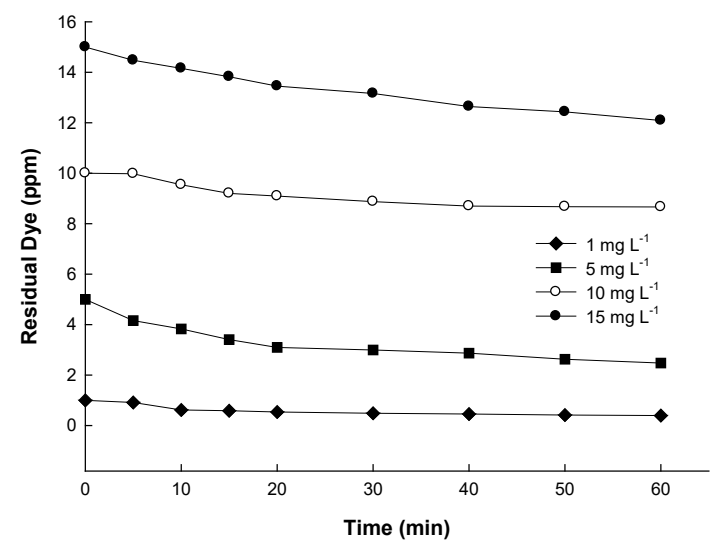

Figure 4. Effect of initial RhB concentration on the ultrasonic decolourization of RhB.

\section{Effect of pH on the Photocatalytic Decolourization of RhB}

Photocatalytic decolourization process is also known to be affected by $\mathrm{pH}$. The effect of the initial $\mathrm{pH}$ of the aqueous medium on the degradation of $\mathrm{RhB}$ by the $\mathrm{TiO}_{2} / \mathrm{UV}$ process was also studied at different $\mathrm{pHs}$ in the range of 3.0-11.0. The results were showed in Figure 3. The photocatalytic decolourization of $\mathrm{RhB}$ was maximum at $\mathrm{pH}$ 3.0. It was found that decolourization rate of $\mathrm{RhB}$ continuated with decreasing slope at $\mathrm{pH}$ 4.5. But, the decolourization of dye increase from $\mathrm{pH} 4.5$ to 3.0, and there is almost no decolourization in dye at higher $\mathrm{pHs}$. At higher $\mathrm{pH}$ values than $\mathrm{pK}_{\mathrm{a}}$ (3.7) of RhB [19], the carboxyl group of cationic form $\left(\mathrm{RhB}^{+}\right)$is deprotonated, thus the dye is transformed into zwitterionic form $\left(\mathrm{RhB}^{ \pm}\right)$[1521]. The RhB molecule has two diethylamine groups, that can be protonated at acidic pHs. Therefore, with decreasing $\mathrm{pH}$, the protonation of RB increases. In addition, the increasing of the oxidation potential of $\mathrm{OH}$ radical in the acidic medium might be another reason for the increase in decolourization rate [22]. Photocatalytic decolourization process has previously been studied [23]. In this study, it was observed that decolourization rate of dye increased with decreasing $\mathrm{pH}$ from 5.5 to 4.0 .

\section{Ultrasonic Decolourization \\ Effect of Initial Concentration of RhB on the Ultrasonic Decolourization}

One important factor influencing the efficiencies of the ultrasonic decolourization is the initial concentration of RhB. In this work, effect of the initial concentration of $\mathrm{RhB}$ on the ultrasonic decolourization was investigated in the values ranging from 1 to $15 \mathrm{mg} \mathrm{L}^{-1}$. The results were shown in Figure 4. As can be seen from this figure, decolourization rate decreases with increasing initial concentration of RhB. An explanation to this behaviour is the fact that as the initial concentration of RhB increases, intermediates form at higher concentrations [24]. Assuming most of the reactions take place at the bubble-liquid interface, with increasing initial concentrations of RB and correspondingly intermediates, the RB decolourization has been limited by the available interfacial area [24].

\section{Effect of Amplitude on the Ultrasonic Decolourization of RhB}

Another important factor influencing the efficiencies of the ultrasonic decolourization is the amplitude. The effect of amplitude was studied

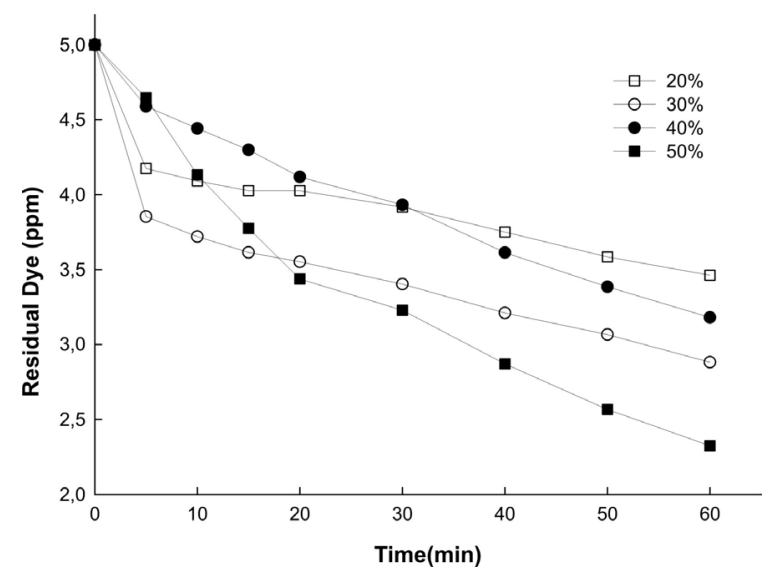

Figure 5. Effect of amplitude on the ultrasonic decolourization of RhB. 


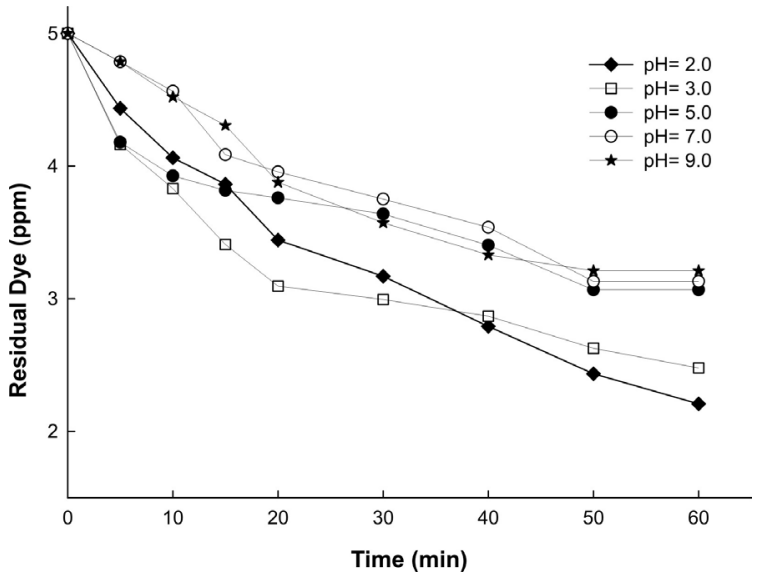

Figure 6. Effect of $\mathrm{pH}$ on the ultrasonic decolourization of $\mathrm{RhB}$.

in the range of $20-50 \%$. Results were showed in Figure 5. As can be seen in the figure, final concentration of RhB decreases with increasing the amplitude. In this case, it is due to higher energy dissipated to the system with decreasing volume at the same energy input [25].

\section{Effect of pH on the Ultrasonic Decolourization of RhB}

The effect of $\mathrm{pH}$ on the ultrasonic decolourization of $\mathrm{RhB}$ was studied in the $\mathrm{pH}$ range of 2.0-9.0. The results were showed in Figure 6 . It was found that the decolourization activity of RhB increased with decreasing $\mathrm{pH}$ values. Decrease of decolourization rate with increase in $\mathrm{pH}$ is due to dissociation of $-\mathrm{COOH}$ sites of dye, so that retards to diffuse into the reactive zone (bubbleliquid interface) in which uncombined $\cdot \mathrm{OH}$ concentration is maximum [12].

The ultrasonic decolourization of $\mathrm{RhB}$ was maximum at $\mathrm{pH}$ 2.0. It was found that rate of decolourization of RhB gradually preceded with decreasing slope up to $\mathrm{pH}$ 3.0, but ah higher $\mathrm{pHs}$ there was almost no change in decolourization rate. The RhB molecule has amine groups that can be protonated at acidic $\mathrm{pH}$. Therefore with decreasing $\mathrm{pH}$, the protonation of $\mathrm{RhB}$ increases. In addition, the increasing of the oxidation potential of $\mathrm{OH} \cdot$ radical in the acidic medium might be another reason for the increase in decolourization rate [16]. Decreasing of decolourization rate by increase of $\mathrm{pH}$ is due to dissociation of $-\mathrm{COOH}$ sites of dye, so that retards it to diffuse into the reactive zone (bubble-liquid interface), where uncombined $\cdot \mathrm{OH}$ concentration is

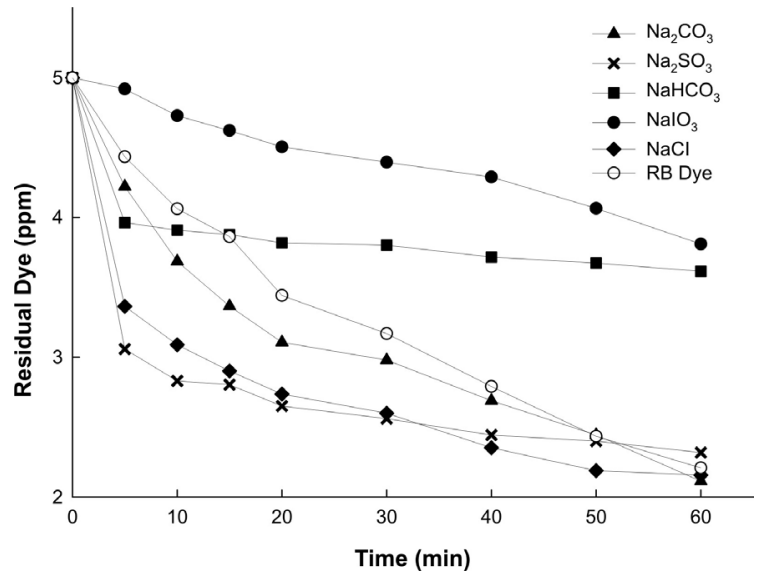

Figure 7. Effect of $\mathrm{Na}_{2} \mathrm{CO}_{3}, \mathrm{Na}_{2} \mathrm{SO}_{3}, \mathrm{NaHCO}_{3}, \mathrm{NaCl}$ and $\mathrm{NaIO}_{3}$ on the ultrasonic degradation of RhB.

maximum [12].

At high pHs dye solutions undergo sonolytic decolourization at a much slower rate. At higher $\mathrm{pHs}, \mathrm{RhB}$ is present in its zwitterion form and does not readily accumulate at the bubble interface. In strong acidic pHs, RhB exists in higher concentrations at the bubble interface and thus, is more readily subjected to the $\mathrm{OH}$ radical attack. The enhancement of decolorization rate in strong basic conditions ( $\mathrm{pH}$ 11-13) may be caused by the change of hydrophobic property of the dye [24].

\section{Effect of $\mathrm{Na}_{2} \mathrm{CO}_{3}, \mathrm{NaHCO}_{3}, \mathrm{NaCl}, \mathrm{Na}_{2} \mathrm{SO}_{3}$ and $\mathrm{NaIO}_{3}$ on the Ultrasonic Decolorization of RhB} One of the aims of the study was also to investigate the effect of salts such as $\mathrm{Na}_{2} \mathrm{CO}_{3}, \mathrm{NaHCO}_{3}, \mathrm{NaCl}$, $\mathrm{Na}_{2} \mathrm{SO}_{3}$ and $\mathrm{NaIO}_{3}$ on the ultrasonic decolorization of $\mathrm{RhB}$. The salt effect on the decolorization process was investigated with the same way. The results were showed in Figure 7 . As can be seen from the figures, the ultrasonic decolorization of $\mathrm{RhB}$ was significantly decreased in the presence of $\mathrm{IO}_{3}^{-}$and $\mathrm{HCO}_{3}^{-}$ions whereas its effectiveness increased significantly in the presence $\mathrm{SO}_{3}{ }^{2-}, \mathrm{Cl}^{-}$ ions and partly in the presence $\mathrm{CO}_{3}{ }^{2-}$ ion. Addition of $\mathrm{NaCl}$ can increase the hydrophilicity, the surface tension and ionic strength of the aqueous phase and decrease the vapour pressure [26]. Addition of salt to aqueous solution of dye pushes RhB molecules from the bulk aqueous phase to the bulk-bubble interface $[26,27]$.

The enhancement of $\mathrm{RhB}$ decolorization is due to the formation of carbonate radical, which 

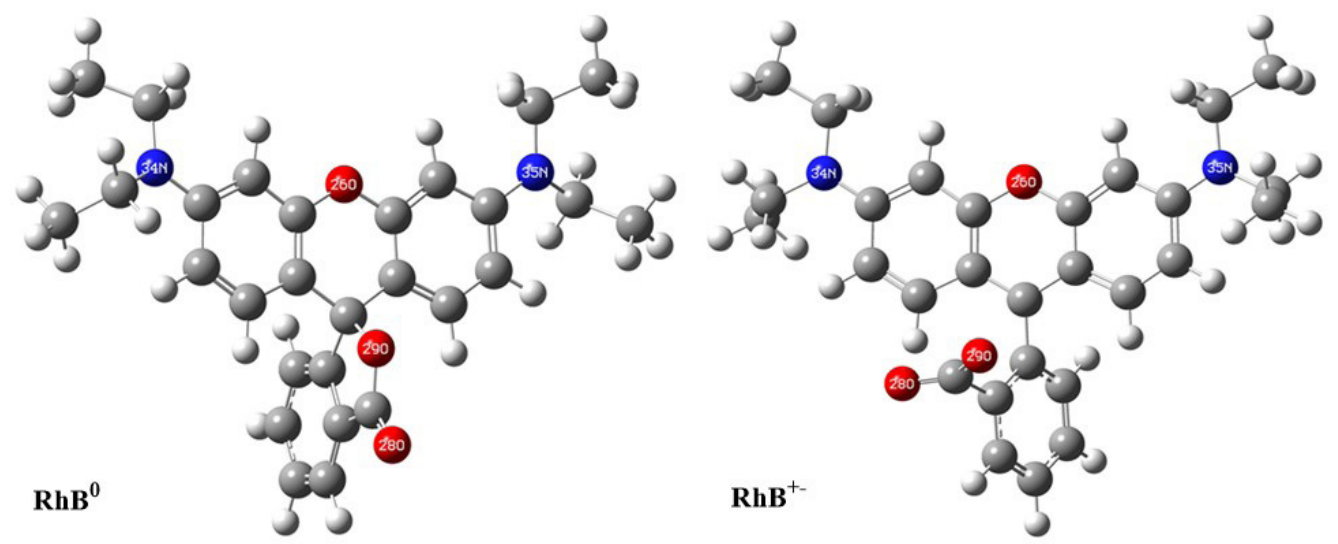

Figure 8. Optimized structures of $\mathrm{RhB}^{\circ}$ and $\mathrm{RhB}^{+-}$with atomic labelling.

may react more effectively than $\mathrm{OH}^{\cdot}$ radical with dye molecules [28]. The addition of bicarbonate had a negative effect on the decolorization rate for higher RhB concentrations (3 and $5 \mathrm{mg} \mathrm{L}^{-1}$ ) [28]. Additionally, $\mathrm{Na}_{2} \mathrm{CO}_{3}$ and $\mathrm{Na}_{2} \mathrm{SO}_{3}$ have alkaline character; therefore such salts neutralize the RB having acidic character. As a result, it may be said that decomposition increased to change the load distribution.

\section{Computational Results}

Optimized structures of $\mathrm{RhB}^{\circ}$ and $\mathrm{RhB}^{+}$ compounds are obtained at HF/6-31G level and represented in Figure 8.

Thermodynamic parameters which are total energy $\left(E_{\text {TOTAL }}\right)$, enthalpy $(H)$ and Gibbs free energy (G) are calculated as $-1410.102451,-1410.101507$ and -1410.190419 a.u. for $\mathrm{RhB}^{\circ}$ while -1410.084832 , -1410.054342 and -1410.149451 a.u. for $\mathrm{RhB}^{+-}$. According to these results, $\mathrm{RhB}^{\circ}$ is more stable than $\mathrm{RhB}^{+}$. The equilibrium between these compounds has been mentioned in "Introduction section".
Equilibrium constant of its is calculated as 0.999 and it is too close to equilibrium.

Chemical reactivity of mentioned compounds are investigated by computational method. For this goal, some quantum chemical parameters which are $\mathrm{E}_{\text {номо' }} \mathrm{E}_{\text {LUMO' }^{\prime}} \mathrm{E}_{\text {GAP' }} \sigma, \mathrm{CP}, \mathrm{N}$ and $\mu$ are calculated and given in Table 1.

Energy of HOMO is significant parameters to determine the chemical reactivity ranking. $\mathrm{E}_{\text {номо }}$ is associated with electron donating ability and chemical reactivity of molecules increases with the increasing of $E_{\text {номо }}[29,30]$. According to $E_{\text {номо' }}$ chemical reactivity ranking should be as follow:

$\mathrm{RhB}^{0}>\mathrm{RhB}^{+}$

One of the other important parameter is LUMO energy. $E_{\text {LUMO }}$ is related with electron accepting from appropriate molecule. If $\mathrm{E}_{\text {Lumo }}$ is decisive parameter, chemical reactivity ranking should be as follow:

Table 1. Calculated quantum chemical descriptors for mentioned compounds in gas phase.

\begin{tabular}{ccccccc}
\hline Compounds & EHOMO $^{\mathrm{a}}$ & ELUMO $^{\mathrm{a}}$ & EGAPa & $\mathrm{I}^{\mathrm{a}}$ & $\mathrm{A}^{\mathrm{a}}$ & $\eta^{\mathrm{a}}$ \\
\hline $\mathrm{RhB}^{\circ}$ & -7.654 & 2.395 & 10.049 & 7.654 & -2.395 & 5.025 \\
\hline $\mathrm{RhB}^{+-}$ & -7.913 & 0.313 & 8.226 & 7.913 & -0.313 & 4.113 \\
\hline Compounds & $\sigma^{\mathrm{b}}$ & $\chi^{\mathrm{a}}$ & $\mathrm{CP}$ & $\omega^{\mathrm{a}}$ & $\mathrm{Nb}$ & $\mu \mathrm{C}$ \\
\hline $\mathrm{RhB}^{\circ}$ & 0.199 & 2.629 & -2.629 & 0.688 & 1.453 & 6.838 \\
\hline $\mathrm{RhB}^{+-}$ & 0.243 & 3.800 & -3.800 & 1.755 & 0.570 & 15.949 \\
\hline
\end{tabular}

a in $\mathrm{eV},{ }^{\mathrm{b}}$ in $\mathrm{eV}-1, \mathrm{c}$ in Debye. 
$\mathrm{RhB}^{+-}>\mathrm{RhB}^{\circ}$

Other important parameter is $\mathrm{E}_{\mathrm{GAP}}$ and chemical reactivity increases with the decreasing of $E_{G A P}$ value [30]. According to $E_{G A P^{\prime}}$ the ranking is given as follow.

$\mathrm{RhB}^{+-}>\mathrm{RhB}^{0}$

The other important parameters are hardness and softness to explain the chemical reactivity ranking. The rule is that hard species prefer to coordinate to hard species and soft molecules to soft molecule. Big molecules are mainly accepted as soft species. The softness of mentioned tautomer ranking should be:

$\mathrm{RhB}^{+-}>\mathrm{RhB}^{\circ}$

According to softness values, $\mathrm{RhB}^{+-}$is found as the most reactive. Chemical potential is other important parameters to determine the chemical reactivity ranking. Chemical potential is directly proportional with gibbs free energy and these parameters can be related with spontaneity. The chemical reactivity increases with decreasing of chemical potential and reactivity ranking should be as follow:

$\mathrm{RhB}^{+-}>\mathrm{RhB}^{0}$

Other important parameter is nucleophilicity index. The nucleophilicity index shows the ability of electron donating. The chemical reactivity ranking increases with increasing the $\mathrm{N}$ value. According to the $\mathrm{N}$ value, chemical reactivity ranking should be: $\mathrm{RhB}^{0}>\mathrm{RhB}^{+}$

Azo-enol tautomer is the most reactive in gas phase than other areas. The last parameter is dipole moment. Chemical reactivity of molecules increases with increasing of this parameter. If dipole moment is decisive to determine the chemical reactivity ranking, ranking should be as follow.

$\mathrm{RhB}^{+-}>\mathrm{RhB}^{0}$

According to whole results, $\mathrm{RhB}^{+-}$is more reactive than $\mathrm{RhB}^{\circ}$. This result implies that reactivity of solutions decreases after the decolorization.

\section{CONCLUSION}

In this work, decolorization of RhB was investigated by using photocatalytic and ultrasonic processes. Among these methods, Ag-loading/UV photocatalytic process was found to be the most effective method. In this process approximately $100 \%$ decolorization was observed at treatment of $20 \mathrm{~min}$. $\mathrm{TiO}_{2} / \mathrm{UV}$ photocatalytic process was found to be secondly an effective process for decolorization of RhB. While the amount of decolorization obtained by ultrasonic process are $31 \%$ and $56 \%$, the amount of decolorization obtained by photocatalytic process for treatments of 20 and $60 \mathrm{~min}$ are $70 \%$ and $100 \%$, respectively. As a result, $\mathrm{Ag}$-loading/UV photocatalytic process of dye reported in here is more advantageous than those of the other oxidation processes since it takes a few minutes, and moreover it requires less energy, and the catalyst can be reused for several times, and does not require further treatment. Optimized structures of $\mathrm{RhB}^{\circ}$ and $\mathrm{RhB}^{+-}$are calculated at $\mathrm{HF} / 6-31 \mathrm{G}$ level in gas phase. $\mathrm{RhB}^{0}$ is determined as more stable than $\mathrm{RhB}^{+-}$by using thermodynamic parameters. The equilibrium constant between $\mathrm{RhB}^{+-}$and $\mathrm{RhB}^{\circ}$ is calculated as 0.999. Additionally, chemical reactivity of mentioned compounds examined in detail by using quantum chemical parameters and $\mathrm{RhB}^{+-}$is defined as more reactive than $\mathrm{RhB}^{\circ}$.

\section{ACKNOWLEDGEMENTS}

The numerical calculations reported in this paper are performed at TUBITAK ULAKBIM, High Performance and Grid Computing Center (TRUBA Resources).

\section{References}

1. C. Hachem, F. Bocquillon, O. Zahraa, M. Bouchy, Decolourization of textile industry wastewater by the photocatalytic degradation process, Dyes Pigments, 49 (2001) 117-125.

2. Y. Ma, J. Yao, Photodegradation of Rhodamine B catalyzed by $\mathrm{TiO} 2$ thin films, J. Photoch. Photobiol. A., 116 (1998) 167-170.

3. M. Muruganandham, M. Swaminathan, TiO2- UV photocatalytic oxidation of reactive yellow 14: Effect of operational parameters, J. Hazard. Mater. B., 135 (2006) 78-86.

4. X. Chen, S.S. Mao, Titanium dioxide nanomaterials: synthesis, properties, modifications, and applications, Chem. Rev., 107 (2007) 2891-2959. 
5. A.L. Linsebigler, G. Lu, J.T. Yates Jr, Photocatalysis on TiO2 surfaces: principles, mechanisms, and selected results, Chem. Rev., 95 (1995) 735-758.

6. D.F. Ollis, E. Pelizzetti, N. Serpone, Destruction of water contaminants, Environ. Sci. Technol., 25 (1991) 1523-1529.

7. T. Wu, T. Lin, J. Zhao, H. Hidaka and N. Serpone, TiO2assisted photodegradation of dyes. 9: photooxidation of a squarylium cyanine dye in aqueous dispersions under visible light irradiation, Environ. Sci. Technol., 33 (1999) 1379-1387.

8. S. Kutsuna, M. Toma, K. Takeuchi, T. Ibusuki, Photocatalytic degradation of some perfluoroalkyl ethers on $\mathrm{TiO} 2$ particles in air: the dependence on the dark-adsorption, the products, and the implication for a possible tropospheric sink, Environ. Sci. Technol., 33 (1999) 1071-1076.

9. M. Fox, M. Dulay, Heterogeneous photocatalysis, Chem. Rev., 93 (1993) 341- 357.

10. P.V. Kamat, Photochemistry on nonreactive and reactive (semiconductor) surfaces, Chem. Rev., 93 (1993) 207-300.

11. M. Sökmen, D.W. Allen, F. Akkaş, N. Kartal, F. Acar, Photo-degradation of some dyes using Ag-loaded titaniumdioxide, Water Air Soil Poll., 132 (2001) 153163.

12. R. Kidak, N.H. Ince, Effects of operating parameters on sonochemical decomposition of phenol, J. Hazard. Mater., 137 (2006) 1453-1457.

13. N.H. Ince, G. Tezcanlı-Güyer, Impacts of $\mathrm{pH}$ and molecular structure on ultrasonic degradation of azo dyes, Ultrasonics., 42 (2004) 591-596.

14. E. Manousaki, E. Psillakis, N. Kalogerakis, D. Mantzavinos, Degradation of sodium dodecylbenzene sulfonate in water by ultrasonic irradiation, Water Res., 38 (2004) 3751-3759.

15. R.W. Ramette, E.B. Sandell, Rhodamine B equilibria, J. Am. Chem. S., 78 (1956) 4872-4877.

16. M. Kondo, W. Jardim, Photodegradation of chloroform and urea using Ag-loaded titanium dioxide as catalyst, Water Res., 25 (1991) 823-827.

17. GaussView 5.0, Gaussian Inc. Wallingford, CT, USA, 2009.

18. Gaussian 09, rev. D-01, Gaussian Inc. Wallingford, CT, USA, 2013.
19. N.K. Temel, M. Sökmen, New catalyst systems for the degradation of chlorophenols, Desalination, 281 (2011) 209-214

20. S. Woislawski, The spectrophotometric determination of ionization constants of basic dyes, J. Am. Chem. Soc., 75 (1953) 5201-5203.

21. X. Wang, Z. Yao, J. Wang, W. Guo, G. Li, Degradation of reactive brilliant red in aqueous solution by ultrasonic cavitation, Ultrason. Sonochem., 15 (2008) 43-48.

22. S. Lodha, A. Jain, P.B. Punjabi, A novel route for waste water treatment: Photocatalytic degradation of rhodamine B, Arab.J. Chem., 4 (2011) 383-387.

23. M. A. Behnajady, N. Modirshahla, S. Bavili Tabrizi, S. Molanee, Ultrasonic degradation of rhodamine $B$ in aqueous solution: Influence of operational parameters, J. Hazard. Mater., 152 (2008) 381-386.

24. M. A. Behnajady, N. Modirshahla, M. Shokri, B. Vahid, Effect of operational parameters on degradation of malachite green by ultrasonic irradiation, Ultrason. Sonochem., 15 (2008) 1009-1014.

25. J. D. Seymour, R. G. Gupta, Oxidation of aqueous pollutants using ultrasound: salt induced enhancement, Ind. Eng. Chem. Res., 36 (1997) 34533457.

26. S. Fındık, G. Gunduz, Sonolytic degradation of acetic acid in aqueous solutions, Ultrason. Sonochem., 14 (2007) 157-162.

27. S. Merouani, O. Hamdaoui, F. Saoudi, M. Chiha, Sonochemical degradation of Rhodamine $B$ in aqueous phase: Effects of additives, Chem. Eng. J., 158 (2010) 550-557.

28. S. Merouani, O. Hamdaoui, F. Saoudi, M. Chiha, C. Pétrier, Influence of bicarbonate and carbonate ions on sonochemical degradation of Rhodamine B in aqueous phase, J. Hazard. Mater., 175 (2010) 593-599.

29. K. Sayin, D. Karakaş, Quantum chemical studies on the some inorganic corrosion inhibitors, Corros. Sci., 77 (2013) $37-45$.

30. K. Sayin, D. Karakas, N. Karakus, T. Alagöz Sayin, Z. Zaim, S. Erkan Kariper, Spectroscopic investigation, FMOs and NLO analyses of $\mathrm{Zn}(\mathrm{II})$ and $\mathrm{Ni}(\mathrm{II})$ phenanthroline complexes: A DFT approach, Polyhedron., 90 (2015) 139-146. 
